\title{
The subcronic effects of acetamipride on the global DNA methylation levels in Sprague-Dawley rat brain and liver
}

\author{
Yağmur Emre Arıcan' (1D, Ecem Fatma Karaman ${ }^{1,2}$ (1), Sibel Özden¹ \\ 'Department of Pharmaceutical Toxicology, Faculty of Pharmacy, Istanbul University, Istanbul, Turkey \\ 2Department of Pharmaceutical Toxicology, Faculty of Pharmacy, Biruni University, Istanbul, Turkey
}

ORCID IDs of the authors: Y.E.A. 0000-0002-6910-2553; E.F.K. 0000-0002-1504-4546; S.0̈. 0000-0002-1662-2504.

Cite this article as: Arıcan YE, Karaman EF, Özden S (2019). The subcronic effects of acetamipride on the global DNA methylation levels in Sprague-Dawley rat brain and liver. Istanbul J Pharm 49 (3): 167-172.

\begin{abstract}
Acetamiprid, which is a neonicotinoid insecticide, is used to control leafy vegetables, fruiting vegetables, fir seeds, citrus fruits, pome fruits, grapes, cotton and ornamental plants and absorbent insects on flowers. The present study aim to evaluate global DNA methylation and gene expression of DNA methylation related enzymes in liver and brain tissues of male Sprague-Dawley rats after a 90-day subchronic exposure to acetamiprid at low doses of 12.5, 25 and $35 \mathrm{mg} / \mathrm{kg}$ body weight (b.w.). Global DNA methylation resulted in a significant decrease in the levels of 5 -methylcytosine $(5-\mathrm{mC} \%$ ) at the doses of 25 and $35 \mathrm{mg} / \mathrm{kg}$ b.w. in the liver and $35 \mathrm{mg} / \mathrm{kg}$ b.w. in the brain compared to the vehicle control group. Consistently, expression of DNA methyltransferase enzymes decreased at doses of $12.5,25$ and $35 \mathrm{mg} / \mathrm{kg}$ b.w. in liver and $35 \mathrm{mg} / \mathrm{kg} \mathrm{b.w}$. in brain. It has been suggested that non-genotoxic (epigenetic) mechanisms may be involved in the toxicity of acetamiprid and further investigations are needed to elucidate the epigenetic effects of neonicotinoid insecticides.
\end{abstract}

Keywords: Acetamiprid, DNA methylation, Sprague-Dawley rats, liver, brain

\section{INTRODUCTION}

Pesticides are defined as substances or mixtures of substances used to remove, reduce, suppress or degrade harmful organisms in order to increase productivity in agriculture. Pesticides are claimed to be quite useful as a result of their use in appropriate doses and conditions for their intended purpose. However, when they are used incorrectly and in higher than recommended doses, they harm human health as well as increase environmental pollution and affect other living things. Neonicotinoids are a relatively new type of insecticide used to control a variety of pests in agriculture and livestock (Honda et al. 2006). These pesticides are currently preferred to organophosphates and carbamates throughout the world owing to their ability of resistance against day light and higher toxicity to insects than mammals and aquatic organisms because of their affinity to the nicotinic acetylcholine receptors in insects (Kiriyama et al. 2003; Tomizawa and Casida, 2003; Casida and Quistad, 2004; Whitacre and Ware, 2004; Ford 2008; Yu 2008). Neonicotinoids are systemic acting insecticides and affect the central nervous system of insects, resulting in paralysis and death. They can also be persistent in the environment. Some neonicotinoids are suspected to be carcinogenic and mutagenic in mice (Dich et al. 1997; Office of Prevention, Pesticides and Toxic Substances 2003; Green et al. 2005). Acetamiprid (N-[(6-chloropyridin-3-yl)methyl]-N'-cyano-N-methylethanimidamide), a neonicotinoid pesticide, was the second insecticide to be manufactured in this group after the launch of imidacloprid and was first marketed in Japan under the brand name Mospilan (Yamamoto and Casida 1999; Ünver and Uysal 2014). It has been reported that acetamiprid is widely used in agriculture in Turkey (Kocaman and Topaktaş 2007). Acetamiprid is a selective agonist of nicotinic acetylcholine receptor in postsynaptic membrane. $\mathrm{LD}_{50}$ value of acetamiprid is 140-417 mg/kg body weight (b.w.) in different rat strains (Kanungo and Solecki 2011 ). 
Acetamiprid may lead to oxidative damage by producing reactive oxygen species in target tissues (Yao et al. 2006; Ford et al. 2011; Zhang et al. 2011). Additionally, it has been reported that chronic exposure to acetamiprid caused disturbance of matrix oxidative status, and a loss of mitochondrial membranes integrity in rat brain via generating reactive oxygen species (Gasmi et al. 2016 and 2017). Acetamiprid accumulates in the brain of murine and rats (Devan et al. 2015; Terayama et al. 2016). Besides, it can cause changes in brain functions -such as the break-down of learning ability (Mondal et al. 2014; Mandal et al. 2015). In a few studies, the genotoxic and cytotoxic effects of acetamiprid have been investigated. It has been reported that acetamiprid induced frequency of sister chromatid exchange, chromosomal aberrations, and micronucleus formation in human peripheral lymphocytes (Kocaman and Topaktas 2007), micronucleus formation and DNA damage in Caco-2 cells (Cavas et al. 2012) and micronucleus formation and DNA damage in human lung fibroblast cells (Cavas et al. 2014), while acetamiprid did not increase micronucleus formation in peripheral blood lymphocytes (Muranli et al. 2015). According to these studies results on the mechanisms of action in acetamprid toxicity have been controversial. It has become crucial for evaluation of possible genotoxic and cytotoxic effects of acetamiprid on living organisms to take place, due to it becoming increasingly widespread in the world.

DNA methylation, one of the most studied non-genotoxic (epigenetic) modifications, plays an important role in cell proliferation and various diseases such as cancer and diatebetes (Baylin 1997; Moggs et al. 2004; Jones and Baylin 2007; Kulis and Esteller 2010; Anderson et al. 2012; Bansal and Pinney 2017). DNA methylation contributes to alterations in gene expression of key molecular pathways including global DNA hypomethylation and hypermethylation of CpG islands of tumor suppressor genes (Baylin et al. 1986; Watson and Goodman 2002). There has only been one study that shows alterations of global and gene-spesific DNA methylation after acetamiprid exposure in mouse embryonic stem cells (Wang et al. 2019). Therefore, we aimed to investigate the role of DNA methylation changes in acetamiprid toxicity. For this purpose, we determined the global levels DNA methylation and gene expression of related enzymes in liver and brain tissues after subcronic acetamiprid exposure to Sprague-Dawley albino adult rats. This is the first study which analyzed the effects of acetamiprid on global DNA methylation as a key molecular mechanism of epigenetic modulation in rat tissues. Because acetamiprid is a neuro-active insecticide and acts as neurotoxic agent and because the liver is the main target organ for acetamiprid metabolism and elimination, we selected brain and liver tissues for the evaluation of DNA methylation analysis.

\section{MATERIALS AND METHODS}

\section{Chemicals}

Acetamiprid, technical purity 97\%, was obtained from a national company (Hektaş Ticaret T.A.Ş. Istanbul, Turkey) and weekly suspended in an aqueous solution of $0.5 \%$ methylcellulose (Merck, Darmstadt, Germany) before use. All other supplements were purchased from Wisent Bioproducts (Saint-
JeanBaptiste, QC, Canada) and sterile plastic materials were purchased from Nest Biotechnology (Jiangsu, China). DNA, RNA isolation kits and cDNA synthesis kits were obtained from Roche Life Sciences (Penzberg, Germany). 5-methylcytosine (5$\mathrm{mC}$ ) DNA ELISA kit was purchased from Epigentek Research (Farmingdale, NY, USA). Syber green master mix was obtained from Bioline (London, UK) and primers for gene expressions were obtained from Sentromer DNA Technologies (Istanbul, Turkey).

\section{Animal treatments}

In this study male Sprague-Dawley albino adult rats, aged 8-12 weeks and weighing 250-375 g were obtained from Aziz Sancar Institute of Experimental Medicine, Istanbul University. The animals were housed throughout the experiment in polypropylene standard cages in which 4-5 animals were placed. Animals were maintained under controlled conditions of temperature at $22-24^{\circ} \mathrm{C}$, normal photoperiod (12-12 h light-dark cycle) and relative humidity of (50 $\pm 10 \%)$. The animals were allowed free access to standard dry pellet diet and tap water ad libitum. The experiments reported here complied with the current laws and regulations of the Turkish Republic on the care and handling of experimental animals and the local ethics committee of experimental animals of Istanbul University (IUHADYEK; 2016/35 and 2016/42).

\section{Experimental design}

The animals were randomly divided into four experimental groups. The substances were administered in the morning (between 09.00 and 11.00 a.m.) to rats who had not fasted.-

Group I (Vehicle control Group): Control rats received intragastrically (i.g.) a vehicle (0.5\% methylcellulose) $(n=11)$.

Group II: Acetamiprid at the dose of $12.5 \mathrm{mg} / \mathrm{kg}$ body weight (b.w). acetamiprid (NOAEL) in a vehicle (0.5\% methylcellulose) was applied to rats i.g. once a day for 90 days $(n=12)$.

Group III: Acetamiprid at the dose of $25 \mathrm{mg} / \mathrm{kg} \mathrm{b.w.} \mathrm{acet-}$ amiprid in a vehicle ( $0.5 \%$ methylcellulose) was applied to rats i.g. once a day for 90 days $(n=12)$.

Group IV: Acetamiprid at the dose of $35 \mathrm{mg} / \mathrm{kg} \mathrm{b.w.} \mathrm{acet-}$ amiprid in a vehicle ( $0.5 \%$ methylcellulose) was applied to rats i.g. once a day for 90 days $(n=13)$.

Selection of treatment concentrations in the present study were based on no observable adverse effect level (NOAEL) of acetamiprid (12.4 mg/kg b.w.), and on increased liver weight and centrilobular hepatocyte hypertrophy for the 90 days rat study (EFSA 2016). At the end of the treatments, the rats were sacrificed on the $90^{\text {th }}$ day by removing a large volume of blood from the orbital veins under inhalation anesthesia induced by diethyl ether. Brain and kidney samples were dissected, placed in a sufficient amount of phosphate buffered saline (PBS) (1x) and immediately stored at $-80^{\circ} \mathrm{C}$ until analysis. The tissues were homogenized in $0.9 \% \mathrm{NaCl}$ using a tissue homogenizer (UltraTurrax T-18, IKA Werke GmbH\&Co., Staufen, Germany) to make up the $10 \%$ homogenate (w/v). After that DNA and RNA isola- 
Arıcan et al. The subcronic effects of acetamipride on the global DNA methylation levels in Sprague-Dawley rat brain and liver

tion was carried out from these homogenates (10\%) of liver and brain tissues.

\section{Global DNA methylation analysis}

Genomic DNA was isolated from liver and brain tissue homogenates (10\%) using the High Pure PCR Template Preparation kit (Roche Life Sciences, Penzberg, Germany) according to the manufacturer's instructions. To measure global levels of 5-mC\%, 100 ng of DNA samples were applied to MethylFlashTM Methylated DNA Quantification kit (Epigentek, Farmingdale, NY) according to the manufacturer's instructions as previously described (Karaman and Ozden 2019).

\section{Gene expression analysis of DNA methyltransferases}

Total RNA was isolated from liver and brain tissues using a High Pure RNA Tissue kit (Roche Life Sciences, Penzberg, Germany). Reverse transcription was performed by Transcriptor First Strand cDNA Synthesis kit (Roche Life Sciences, Penzberg, Germany) from 500 ng of total RNA and the mixture of anchored-oligo(dT) and random hexamer primers. $5 \mu \mathrm{L}$ of the $1 / 10$ diluted RT-reaction was used as the template in real-time quantitative PCR. Gene expressions of DNA methyltransferases such as DNMT1, DNMT3a, DNMT3b, were measured using BioLine SensiFast ${ }^{\mathrm{TM}}$ Syber" No-Rox kit (London, UK) on LightCycler ${ }^{\circ}$ 480 Instrument II (Roche Life Science). Primer sequences and their annealing temperatures of genes are illustrated in Table 1. Evaluations of results for all genes were performed as described previously (Karaman and Ozden 2019).

\section{Statistical analysis}

Results of 5-mC\% levels and gene expression were represented as mean \pm standard deviation (SD). Statistical analysis was performed by ANOVA followed by Dunnett's multiple comparison test using The Statistical Package for the Social Sciences (SPSS) version 21.0 for Windows, statistical program (IBM Corp.; Armonk, NY, USA). P values of less than 0.05 and 0.001 were selected as the levels of significance.

\section{RESULTS}

\section{Effects of acetamiprid on the global DNA methylation levels}

Levels of 5-mC\% were measured after 12.5, 25 and $35 \mathrm{mg} /$ kg b.w. of acetamiprid treatments for 90 days by Elisa kit. 25 and $35 \mathrm{mg} / \mathrm{kg}$ b.w. of acetamiprid treatments resulted in a significant decrease in 5-mC\% status (38.7\%, p $\square 0.05$ and 77\%, $\mathrm{p} \square 0.05$, respectively) in liver comparison with the vehicle control group. 5-mC\% levels reduced significantly (48.7\%, p $\square 0.05$ ) after $35 \mathrm{mg} / \mathrm{kg}$ b.w. of acetamiprid treatments in brain comparison with the vehicle control group (Figure 1).

\section{Effects of acetamiprid on DNA methyltransferases gene expression levels}

We analysed the gene expressions of DNA methyltransferases (DNMT1, DNMT3a, DNMT3b) to support the global DNA methylation results of acetamiprid in liver and brain. In Figure 2a, our data showed that acetamiprid treatments $(12.5,25$ and $35 \mathrm{mg} /$ kg b.w.) significantly decreased expression levels of DNMT1 ( $\geq 1.96$ fold), DNMT3a ( $\geq 2.86$ fold) and DNMT3b ( $\geq 1.95$ fold) in comparison with the vehicle control group. In Figure 2b, 35 mg/ $\mathrm{kg}$ b.w. of acetamiprid significantly decreased expression levels of DNMT1 (2.44 fold), DNMT3a (2.63 fold) and DNMT3b (1.92 fold) in brain in comparison with the vehicle control group.

\section{DISCUSSION}

Due to their low cost and easy application, the use of pesticides have been preferred as a way of combating plant diseases, pests and weeds which cause a loss of significant amounts of the product or product quality at postharvest storage and agricultural production times. Because of unconscious, incorrect applications of pesticides by manufacturers at harvest and

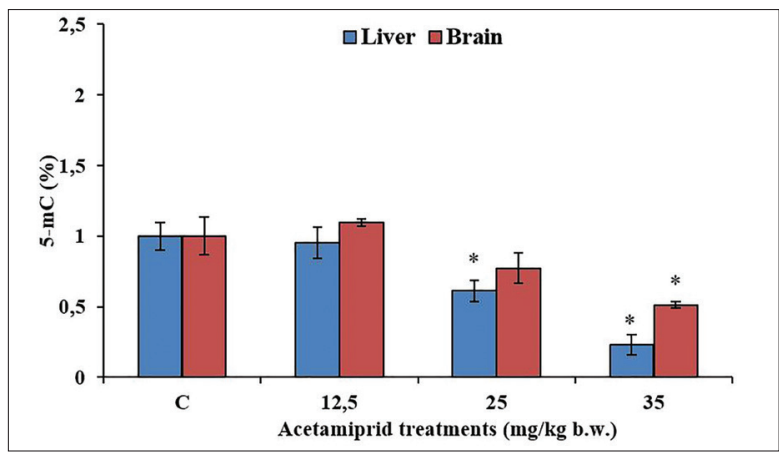

Figure 1. Effects of acetamiprid (12.5, 25 and $35 \mathrm{mg} / \mathrm{kg}$ b.w.) on levels of 5-mC\% in liver and brain tissues of male SpragueDawley albino adult rats. Data are presented as mean \pm SD. Statistically significant changes are indicated by * $p<0.05$. (one way ANOVA-Dunnett post hoc test.).

Table 1. Primers used real-time PCR analysis of DNA methyltransferases and the corresponding annealing temperatures

\begin{tabular}{|c|c|c|c|}
\hline Gene & Primer sequence $\left(5^{\prime}-3^{\prime}\right)$ & $\operatorname{Tm}\left({ }^{\circ} \mathrm{C}\right)$ & Reference \\
\hline \multirow[t]{2}{*}{ DNMT1 } & F: GGTTCTGCGCGGGGACAGAC & 66 & Xu et al. 2015 \\
\hline & R: CCGGCAACATGGCCTCAGGG & & \\
\hline \multirow[t]{2}{*}{ DNMT3a } & F: GGTGTGTGTCGAGAAGCTCA & 60 & Xu et al. 2015 \\
\hline & R: CCAAGGGCCCACTCAATCAT & & \\
\hline \multirow[t]{2}{*}{ DNMT3b } & F: GGGCCGCTACCACGTTCAGG & 64 & Xu et al. 2015 \\
\hline & R: AGGGCCGTCCTGGCTCAAGT & & \\
\hline \multirow[t]{2}{*}{$\beta$-actin } & F: GCGTCCACCCGCGAGTACAA & 64 & Xu et al. 2015 \\
\hline & R: ACATGCCGGAGCCGTTGTCG & & \\
\hline
\end{tabular}




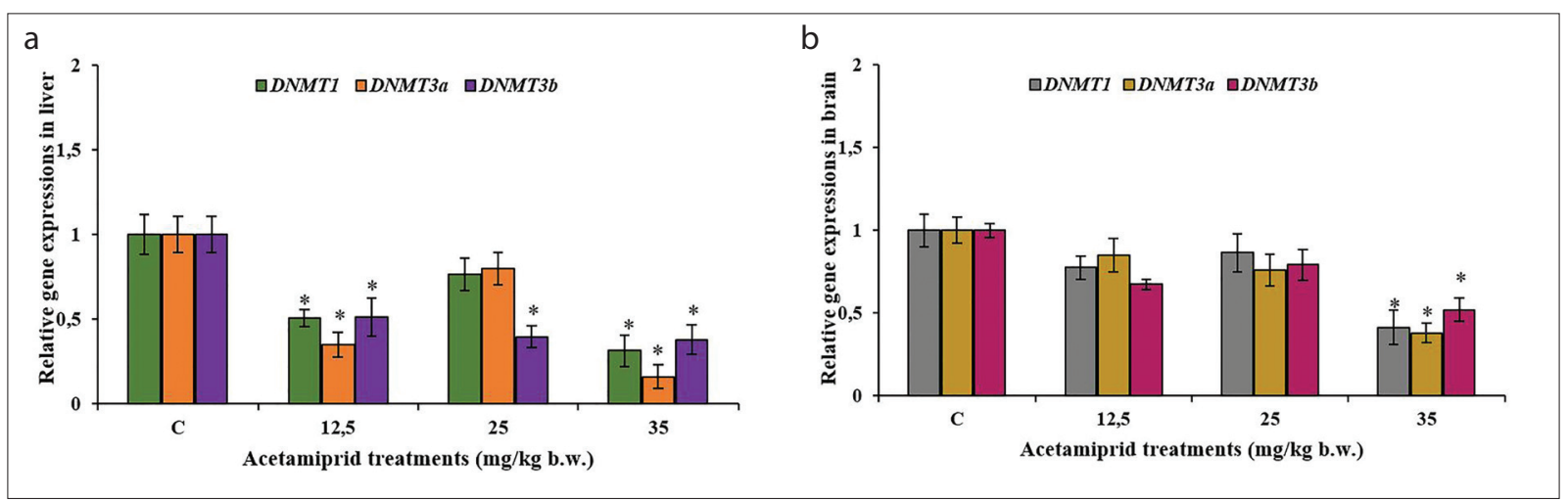

Figure 2. a, b. Effects of acetamiprid (12.5, 25 and $35 \mathrm{mg} / \mathrm{kg}$ b.w.) on relative gene expression levels (DNMT1, DNMT3a, DNMT3b) in liver (a) and brain (b) tissues of male Sprague-Dawley albino adult rats. Data are presented as mean \pm SD. Statistically significant changes are indicated by ${ }^{*} p<0.05 ;{ }^{* *} p<0.001$. (one way ANOVA-Dunnett post hoc test.).

close to the harvest period, the consumption of pesticides above what is necessary to get higher quality products, high levels of drug residues are found on foodstuffs resulting in toxic effects on humans and the environment. Neonicotinoids which act as agonists on the nicotinic acetylcholine receptors (nAChRs) of insects and mammals, form a commercially important pesticide group used as insecticides with increasing use in recent years (Tomizawa and Casida 2003; Sanyal et al. 2008; Simon-Delso et al. 2015).

Acetamiprid is one of the most widely used neonicotinoids which is distributed throughout the body, especially in the liver, kidney, adrenal and thyroid glands, by reaching a high concentration (EFSA Panel 2013). Chakroun et al. (2016) evaluated the hematological, biochemical, and histopathologic effects of acetamiprid on Wistar rats during 60 days and have observed a significant decrease in t body weight gain, hematological parameters and an increase in the relative liver weight. They reported that acetamiprid induced liver toxicity through the increases in the activities of the enzymes including aspartate aminotransferase, alanine aminotransferase, alkaline phosphatase, and lactate dehydrogenase which are the indicators of hepatocellular damage (Chakroun et al. 2016). It has been reported that acetamipride inhalation in humans causes headache, dizziness, nausea, vomiting and other symptoms (Chen et al. 2007).

Investigating epigenetic alterations such as DNA methylation could be useful biomarkers for the toxicity assesments of environmental exposures (Baccarelli and Bollati 2009; Collotta et al. 2013; Greally and Jacobs 2013; Maqbool et al. 2016). It was shown that loss of $5-\mathrm{mC}$ residues termed as global DNA hypomethylation is a common feature in the oncogenesis of many tumor tissues, leading to genomic instability (Gama-Sosa et al. 1983). Emerging evidence indicates that environmental chemical exposure such as dichlorodiphenyltrichloroethane (DDT), organochlorine pesticides, methylmercury chloride or polychlorinated biphenyls, causes epigenetic changes via DNA methylation machinery malfunctions with an increase of carcinogenic risk and developing neurodegeneration (Desaulniers et al. 2009; Shutoh et al. 2009; Kanthasamy et al. 2012; Collotta et al. 2013). It has been reported that blood levels of persistent organic pollutants which accumulate in adipose tissue were inversely related with global DNA methylation levels (Collotta et al. 2013). Kim et al. (2010) observed that exposure to organochlorine pesticides caused global DNA hypomethylation in healthy Koreans. As shown in previous studies it has been emphasized that potential role of epigenetic changes serve as markers for environmental chemical exposures and risk assesment. In the risk assessment process, the evaluation of epigenetic alterations in the toxicity of neonicotinoid insecticides is important. Only one study has been performed on the epigenetic alterations in acetamiprid exposure in cell culture (Wang et al. 2019). Therefore, we aimed to investigate global DNA methylation levels in response to acetamiprid exposure in rat liver and brain. We showed that acetamiprid decreased the global DNA methylation levels in liver and brain tissues of rats, and consistently expression levels of the genes regulating DNA methylation DNMT1, DNMT3a, DNMT3b have also decreased. Wang et al. (2019) showed that neonicotinoids induced global DNA methylation, and imidacloprid had greater effects than acetamiprid in embriyonic stem cells. Ivkovic et al. (2018) suggested that DNA methylation status was disrupted in acetamiprid treated-zebrafish embryos and they reported acetamiprid induced alterations in the methylation levels of certain genes such as CYP19A1, p53, p21 during the early embryonic development of zebrafish.

In conclusion, we showed that global DNA methylation could be associated with acetamiprid toxicity in rat liver and brain tissues. Further studies are needed to better understand the role of epigenetic modifications in the mechanisms of toxicity for acetamiprid and also for other neonicotinoids in the risk assesment processes.

Ethics Committee Approval: The experiments reported here complied with the current laws and regulations of the Turkish Republic on the care and handling of experimental animals and the local ethics committee of experimental animals of Istanbul University (IUHADYEK; 2016/35 and 2016/42).

Peer-review: Externally peer-reviewed.

Author Contributions: Concept - Y.E.A.; Design - Y.E.A., S.Ö.; Supervision - Y.E.A., S.Ö.; Resource - Y.E.A.; Materials - Y.E.A., S.Ö.; Data Collection and/or Processing - Y.E.A., E.F.K., S.Ö.; Analysis and/or Interpretation - Y.E.A., E.F.K., S.Ö.; Literature Search - Y.E.A., E.F.K., S.Ö.; Writing - Y.E.A., E.F.K., S.Ö.; Critical Reviews - Y.E.A., E.F.K., S.Ö. 
Acknowledgements: The authors thank to Prof. Gul Ozhan for the contribution.

Conflict of Interest: The authors have no conflict of interest to declare.

Financial Disclosure: This work was supported partly by Scientific Research Projects Coordination Unit of Istanbul University (Project numbers: TDK-2016- 22054).

\section{REFERENCES}

- Anderson OS, Sant KE, Dolinoy DC (2012). Nutrition and epigenetics: an interplay of dietary methyl donors, one-carbon metabolism and DNA methylation. J Nutr Biochem 23: 853-859. [CrossRef]

- Baccarelli A, Bollati V (2009). Epigenetics and environmental chemicals. Curr Opin Pediatr 21: 243-251. [CrossRef]

- Bansal A, Pinney SE (2017). DNA methylation and its role in the pathogenesis of diabetes. Pediatr Diabetes 18: 167-177. [CrossRef]

- Baylin SB (1997). Tying it all together: epigenetics, genetics, cell cycle, and cancer. Science 277: 1948-1949. [CrossRef]

- Baylin SB, Hoppener JW, de Bustros A, Steenbergh PH, Lips CJ, Nelkin BD (1986). DNA methylation patterns of the calcitonin gene in human lung cancers and lymphomas. Cancer Res $\mathbf{4 6}$ 2917-2922.

- Casida J, Quistad GB (2004). Why insecticides are more toxic to insect than people: the unique toxicology of insects. J Pest Sci 29 : 81-86. [CrossRef]

- Chakroun S, Ezzi L, Grissa I, Kerkeni E, Neffati F, Bhouri R, Sallem A, Najjar MF, Hassine M, Mehdi M, Haouas Z, Ben Cheikh H (2016). Hematological, biochemical, and toxicopathic effects of subchronic acetamiprid toxicity in Wistar rats. Environ Sci Pollut Res Int 23: 25191-25199. [CrossRef]

- $\quad$ Chen LM, Liu HS, Chen N, Du SM (2007). The determination of acetamiprid residues om serum by gas chromatography. Zhonghua Lao Dong Wei Sheng Zhi Ye Bing Za Zhi 25: 191-192.

- Collotta M, Bertazzi PA, Bollati V (2013). Epigenetics and pesticides. Toxicology 307: 35-41. [CrossRef]

- Çavaş T, Çinkılıç N, Vatan Ö, Yılmaz D (2014). Effects of fullerenol nanoparticles on acetamiprid induced cytoxicity and genotoxicity in cultured human lung fibroblasts. Pestic Biochem Phys 114: 1-7. [CrossRef]

- Çavaş T, Çinkılıç N, Vatan Ö, Yılmaz D, Coşkun M (2012). In vitro genotoxicity evaluation of acetamiprid in $\mathrm{CaCo}-2$ cells using the micronucleus, comet and $\mathrm{yH} 2 \mathrm{AX}$ foci assays. Pestic Biochem Physiol 104: 212-217. [CrossRef]

- Desaulniers D, Xiao GH, Lian H, Feng YL, Zhu J, Nakai J, Bowers WJ (2009). Effects of mixtures of polychlorinated biphenyls, methylmercury, and organochlorine pesticides on hepatic DNA methylation in prepubertal female Sprague-Dawley rats. Int J Toxicol 28: 294-307. [CrossRef]

- Devan RS, Mishra A, Prabu P, Mandal T, Panchapakesan S (2015). Sub-chronic oral toxicity of acetamiprid in wistar rats. Toxicol Environ Chem 97: 1236-1252. [CrossRef]

- Dich J, Zahm SH, Hanberg A, Adami HO (1997). Pesticides and cancer. Cancer Causes Control 8: 420-443. [CrossRef]

- European Food Safety Authority (EFSA) 2016. Peer review of the pesticide risk assessment of the active substance acetamiprid. EFSA Journal 14: 1-26. [CrossRef]

- $\quad$ EFSA Panel On Plant Protection Products And Their Residues (PPR) (2013). Scientific Opinion on the developmental neurotoxicity potential of acetamiprid and imidacloprid, Scientific Opinion, European Food Safety Authority (EFSA) Journal, 1-47.
Ford KA (2008). Metabolism, Pharmacokinetics and Toxicology of the Neonicotinoid Insecticides in Mice. 1-7. Berkeley, ABD: University of California, Molecular Toxicology.

- $\quad$ Ford KA, Gulevich AG, Swenson TL, Casida JE (2011). Neonicotinoid insecticides: oxidative stress in planta and metallo-oxidase inhibition. J Agric Food Chem 59: 4860-4867. [CrossRef]

- Gama-Sosa MA, Slagel VA, Trewyn RW, Oxenhandler R, Kuo KC, Gehrke CW, Ehrlich M (1983). The 5-methylcytosine content of DNA from human tumors. Nucleic Acids Research 11: 6883-6894. [CrossRef]

- Gasmi S, Kebieche M, Rouabhi R, Touahria C, Lahouel A, Lakroun Z, Henine S, Soulimani R (2017). Alteration of membrane integrity and respiratory function of brain mitochondria in the rats chronically exposed to a low dose of acetamiprid. Environ Sci Pollut Res Int 24: 22258-22264. [CrossRef]

Gasmi S, Rouabhi R, Kebieche M, Salmi A, Boussekine S, Toualbia N, Taib C, Henine S, Bouteraa Z, Djabri B (2016). Neurotoxicity of acetamiprid in male albino rats and the opposite effect of quercetin. Biotechnol Ind J 12: 113.

- Greally JM, Jacobs MN (2013). In vitro and in vivo testing methods of epigenomic endpoints for evaluating endocrine disruptors. Altex 30: 445-471. [CrossRef]

Green T, Toghill A, Lee R, Waechter F, Weber E, Noakes J (2005). Thiamethoxam induced mouse liver tumors and their relevance to humans part 1: mode of action studies in the mouse. Toxicol Sci 86: 36-47. [CrossRef]

Honda H, Tomizawa M, Casida JE (2006). Neonicotinoid metabolic activation and inactivation established with coupled nicotinic receptor-CYP3A4 and -aldehyde oxidase systems. Toxicol Lett 161: 108-114. [CrossRef]

Ivkovic B, Kitanovic N, Fa S, Andric N (2018). Effects of acetamiprid on gene-specific DNA methylation in zebrafish (Danio rerio) embryos. In Serbian Biochemical Society Eighth Conference (p. 133). Jones PA, Baylin SB (2007). The epigenomics of cancer. Cell 128 683-692. [CrossRef]

Kanthasamy A, Jin H, Anantharam V, Sondarva G, Rangasamy V, Rana A (2012). Emerging neurotoxic mechanisms in environmental factors-induced neurodegeneration. Neurotoxicology 33: 833837. [CrossRef]

Kanungo D, Solecki R (2011). Pesticide residues in food toxicological evaluations. In: WHO, \& FAO (Eds), Joint Meeting of the FAO Panel of Experts on Pesticide Residues in Food and the Environment and the WHO Core Assessment Group on Pesticide Residues. 2, pp. 3-92. Geneva, Switzerland,: World Health Organization.

Karaman EF, Ozden S (2019). Alterations in global DNA methylation and metabolism-related genes caused by zearalenone in MCF7 and MCF10F cells. Mycotoxin Res 35: 309-320. [CrossRef]

Kim KY, Kim DS, Lee SK, Lee IK, Kang JH, Chang YS, Jacobs DR, Steffes M, Lee DH (2010). Association of low-dose exposure to persistent organic pollutants with global DNA hypomethylation in healthy Koreans. Environ Health Perspect 118: 370-374. [CrossRef]

Kiriyama K, Itazu Y, Kagabu S, Nishimura K (2003). Insecticidal and neuroblocking activities of acetamiprid and related compounds. J Pest Sci 28: 8-17. [CrossRef]

- Kocaman AY, Topaktaş M (2007). In vitro evaluation of the genotoxicity of acetamiprid in human peripheral blood lymphocytes. Environ Mol Mutagen 48: 483-490. [CrossRef]

- Kulis M, Esteller M (2010). DNA methylation and cancer. Adv Genet 70: 27-56. [CrossRef]

Mandal PS, Mondal S, Karnam SS, Purohit K (2015). A behavioral study on learning and memory in adult sprague dawley rat in Induced acetamiprid toxicity. Explor Anim Med Res 5: 27-32. 
- Maqbool F, Mostafalou S, Bahadar H, Abdollahi M (2016). Review of endocrine disorders associated with environmental toxicants and possible involved mechanisms. Life Sci 145: 265273. [CrossRef]

- Mondal S, Ghosh RC, Karnam SS, Purohit K (2014). Toxicopathological changes on wistar rat after multiple exposures to acetamiprid. Vet World 7: 1058-1065. [CrossRef]

- Moggs JG, Goodman JI, Trosko JE, Roberts RA (2004). Epigenetics and cancer: implications for drug discovery and safety assessment. Toxicol Appl Pharmacol 196: 422-430. [CrossRef]

- Muranli FDG, Rasgele PG, Kekecoglu M, Kanev M, Özdemir K (2015). Potential genotoxicity of acetamiprid and propineb singly or in combination in cultured human peripheral blood lymphocytes by using MN Assay. Fresenius Environmental Bulletin 24: 3947-3955.

- Office of Prevention, Pesticides and Toxic Substances (2003). Pesticide Thiacloprid Fact Sheet. Environmental Protection Agency (EPA). Washington, DC: United States.

- Sanyal D, Chakma D, Alam S (2008). Persistence of a neonicotinoid insecticide, acetamiprid on chili (Capsicum annum I.). Bull Environ Contam Toxicol 81: 365-368 [CrossRef]

- Shutoh Y, Takeda M, Ohtsuka R, Haishima A, Yamaguchi S, Fujie H, Komatsu Y, Maita K, Harada T (2009). Low dose effects of dichlorodiphenyltrichloroethane (DDT) on gene transcription and DNA methylation in the hypothalamus of young male rats: implication of hormesis-like effects. J Toxicol Sci 34: 469-482. [CrossRef]

- Simon-Delso N, Amaral-Rogers V, Belzunces LP, Bonmatin JM, Chagnon M, Downs C (2015). Systemic insecticides (neonicotinoids and fipronil): trends, uses, mode of action and metabolites. Environ Sci Pollut Res Int 22: 5-34. [CrossRef]

- Terayama H, Endo H, Tsukamoto H, Matsumoto K, Umezu M, Kanazawa T, Ito M, Sato T, Naito M, Kawakami S, Fujino Y, Tatemichi M, Sakabe K (2016). Acetamiprid accumulates in different amounts in murine brain regions. Int J Environ Res Public Health 13: 1-13. [CrossRef]
Tomizawa M, Casida JE (2003). Selective toxicity of neonicotinoids attributable to specificity of insect and mammalian nicotinic receptors. Annu Rev Entomo/ 48: 339-364. [CrossRef]

- Ünver S, Uysal H (2014). Neonikotinoid insektisitlere bağlı olarak Drosophila melanogaster'in AChE aktivitesinde meydana gelen değişikliklerin bitkisel ekstraktlar ile giderilmesi üzerine araştırmalar. Fen Bilimleri Dergisi (CFD), 35(4).

- Wang W, Otsuka S, Nansai H, Ito T, Abe K, Nakao Y, Ohgane J, Yoneda M, Sone H (2019). Epigenetic Effects of Exposure to Insecticide on Early Differentiation of Mouse Embryonic Stem Cells. BioRxiv 628487. [CrossRef]

- Watson RE, Goodman JI (2002). Epigenetics and DNA methylation come of age in toxicology. Toxicol Sci 67: 11-16. [CrossRef]

Whitacre DM, Ware GW (2004). An Introduction to Insecticides. (Radcliffe EB, Hutchison WD, editors, and University of Minnesota; Department of Entomology; College of Food, Agricultural, and Natural Resource Sciences) Retrieved from Radcliffe's IPM World Textbook: https://ipmworld.umn.edu/ware-intro-insecticides, Accessed 13.03.2017

- $\quad$ Xu HX, Qin JZ, Zhang KY, Zeng WX (2015). Dynamic expression profile of DNA methyltransferases in rat testis development. Pol J Vet Sci 18: 549-556. [CrossRef]

- Yamamoto I, Casida JE (1999). Nicotinoid insecticides and the nicotinic acetylcholine receptor. Tokyo: Springer-Verlag. [CrossRef]

- Yao X-H, Jin S, Lv Z-M (2006). Response of superoxide dismutase, catalase, and ATPase activity in bacteria exposed to acetamiprid. Biomed Environ S 19: 309-314.

- $\quad$ Yu SJ (2008). The Need for Pestisides and Their Pattern of Use. In: Yu SJ (ed.) The Toxicology and Biochemistry of Insecticides (pp. 1-6). New York, USA: CRC Press.

- $\quad$ Zhang JJ, Wang Y, Xiang HY, Li MX, Li WH, Ma KG, Wang XZ, Zhang JH (2011). Oxidative stress: role in acetamiprid-induced Impairment of the male mice reproductive system. Agric SciChina 10: 786-796. [CrossRef] 